\title{
Frequency and diversity of small cryptic plasmids in the genus Rahnella
}

Wilfried Rozhon ${ }^{1 *}$, Elena Petutschnig ${ }^{2}$, Mamoona Khan ${ }^{1}$, David K Summers ${ }^{3}$, Brigitte Poppenberger ${ }^{1}$

\begin{abstract}
Background: Rahnella is a widely distributed genus belonging to the Enterobacteriaceae and frequently present on vegetables. Although Rahnella has interesting agro-economical and industrial properties and several strains possess antibiotic resistances and toxin genes which might spread within microbial communities, little is known about plasmids of this genus. Thus, we isolated a number of Rahnella strains and investigated their complements of small plasmids.

Results: In total 53 strains were investigated and 11 plasmids observed. Seven belonged to the ColE1 family; one was ColE2-like and three shared homology to rolling circle plasmids. One of them belonged to the pC194/pUB110 family and two showed similarity to poorly characterised plasmid groups. The $\mathrm{G}+\mathrm{C}$ content of two rolling circle plasmids deviated considerably from that of Rahnella, indicating that their usual hosts might belong to other genera. Most ColE1-like plasmids formed a subgroup within the ColE1 family that seems to be fairly specific for Rahnella. Intriguingly, the multimer resolution sites of all ColE1-like plasmids had the same orientation with respect to the origin of replication. This arrangement might be necessary to prevent inappropriate synthesis of a small regulatory RNA that regulates cell division. Although the ColE1-like plasmids did not possess any mobilisation system, they shared large parts with high sequence identity in coding and non-coding regions. In addition, highly homologous regions of plasmids isolated from Rahnella and the chromosomes of Erwinia tasmaniensis and Photorhabdus luminescens could be identified.

Conclusions: For the genus Rahnella we observed plasmid-containing isolates at a frequency of 19\%, which is in the average range for Enterobacteriaceae. These plasmids belonged to diffent groups with members of the ColE1family most frequently found. Regions of striking sequence homology of plasmids and bacterial chromosomes highlight the importance of plasmids for lateral gene transfer (including chromosomal sequences) to distinct genera.
\end{abstract}

\section{Background}

Rahnella, a genus of the Enterobacteriaceae, is commonly found in the rhizosphere $[1,2]$ and phyllosphere [3], seeds [4], fruits [5,6], water [7] and intestinal tracts of herbivores including snails, slugs, and even American mastodon remains $[8,9]$. In addition, Rahnella strains have been isolated from the extreme environment of uranium and nitric acid contaminated soil adjacent to disposal ponds of the DOE Field Research Centre in the Oak Ridge National Laboratory Reservation in Tennessee [10]. The genus Rahnella comprises three closely related species that cannot be phenotypically

\footnotetext{
*Correspondence: wilfried.rozhon@univie.ac.at

'Max F Perutz Laboratories, University of Vienna, Dr Bohrgasse 9, 1030 Vienna, Austria
} Vienna, Austria

differentiated: Rahnella aquatilis, Rahnella genomospecies 2 and Rahnella genomospecies 3 [8].

In recent years interest in certain Rahnella strains increased because of their remarkable properties. Rahnella might be useful for control of plant pathogens like Erwinia amylovora causing fire blight of apple trees or Xanthomonas campestris, the causal agent of black rot $[11,12]$. Several strains seem to improve plant nutrition, as they are able to fix nitrogen [2] and to solubilise hydroxyapatite, thus converting phosphate to a plant utilisable form [13]. The production of polysaccharides, especially levan and lactan, by different Rahnella isolates is intensively studied, because these macromolecules have ideal properties for industrial applications [14-16]. Some reports have described Rahnella as an 
opportunistic human pathogen but infections with Rahnella are usually limited to immunocompromised patients and recovery is rapid [17-19]. However, antibiotic resistances and enterotoxins encoded by several strains [20-22] might spread within microbial communities. Thus, an improved understanding of mobile genetic elements of Rahnella is crucial to assess the potential of lateral gene transfer to other species including human pathogens. Nevertheless, although Rahnella is widely distributed and frequent on vegetables and therefore likely to be routinely present in the human diet, little is known about plasmids of this genus. So far only one Rahnella plasmid, pHW15, has been characterised [6]. pHW15 belongs to the ColE1 family, is nonmobile and stably maintained even in the absence of selective pressure. To gain insights into the frequency, diversity and evolution of small (less than $15 \mathrm{~kb}$ ) Rahnella plasmids, we isolated strains from different geographic origins and sample materials. Most plasmids belonged to the ColE1 family but we also found members of other groups, including plasmids replicating by the rolling circle mechanism. In addition, sequence analysis provided evidence for lateral gene transfer within Rahnella as well as between Rahnella and other genera.

\section{Results and Discussion}

\section{Isolation of strains, screening for plasmids and cloning}

Forty five Rahnella strains were isolated from vegetables obtained from supermarkets or sampled from fields. Isolates from the same sample were only included in the collection if they differed in at least one biochemical characteristic or the partial $16 \mathrm{~S}$ rRNA gene sequence to avoid multiple sampling of the same strain. This collection was complemented by 6 strains obtained from culture collections and two strains that had been previously investigated for plasmid content (Table 1). Thus, in total 53 strains were included in this study and 10 of them (19\%) contained small plasmids, as revealed by DNA isolation and subsequent gel electrophoresis. Nine of these strains contained one plasmid and one of them had two. Therefore, 10 novel plasmids were detected in addition to $\mathrm{pHW} 15$. Their sizes ranged from 2.9 to 7.0 $\mathrm{kb}$, which is typical for small plasmids from enterobacteria [23]. The method we used for detection of plasmid DNA preferentially selects for small plasmids (below 20 - $30 \mathrm{~kb}$ ) rather than large DNA molecules. Thus, the presence of large plasmids in the investigated strains cannot be excluded. Cloning and sequencing of the isolated plasmids revealed that the majority of them (7 of $11 ; 64 \%$ ) belonged to the ColE1 group (plasmids pHW15 to pHW42, Fig. 1). In addition, one ColE2-like plasmid (pHW66) was isolated. The three remaining plasmids (pHW121, pHW104 and pHW126) are likely to replicate by the rolling circle mechanism. pHW121 belonged to the well-described pC194/pUB110 family, while pHW104 and pHW126 showed homology to different groups of poorly characterised plasmids.

\section{ColE1-like plasmids}

The replication regions of the ColE1-like plasmids showed the typical elements: RNA I, RNA II, a single strand initiation site $(s s i)$ and a terH sequence for termination of lagging-strand synthesis. Phylogenetic analysis based on the RNA II sequence revealed that pHW15, pHW120, pHW114A, pHW114B, pHW30076 and pHW 4594 represented a subgroup within the ColE1 family together with pECA1039, a plasmid isolated from Pectobacterium atrosepticum [24]. pHW42 did not fall into this subgroup and was more related to other ColE1-like plasmids (Fig. 2A). Not only the replication regions but also the multimer resolution sites ( $m r s$ ) were closely related in all ColE1-like plasmids of Rahnella. In a phylogenetic tree based on mrs sites (Fig. 2B) most plasmids isolated from Rahnella formed a cluster similar to the RNA II tree, confirming that they form a separate class within the ColE1 family.

It might be thought surprising that all multimer resolution sites of plasmids depicted in Fig. 1 are in the same orientation with respect to the replication origin (oriV). This is also true for all ColE1-like plasmids in Fig. 2A. The explanation for this observation may lie in the intimate association of replication control and multimer resolution in the stable maintenance of ColE1-like plasmids. Because all of the ColE1 replication origins in a cell function independently, plasmid dimers (which have two origins) replicate twice as often as monomers. As a result, dimers accumulate rapidly and clonally in a process known as the dimer catastrophe [25]. RNAIRNAII copy number control counts origins rather than plasmids, so a dimer is not differentiated from two monomers. Consequently the copy number (i.e the number of independent molecules) of dimers is approximately half that of monomers. ColE1 lacks active partition, so plasmid stability requires the maintenance of a high copy number. As a result the copy number depression caused by dimer accumulation causes plasmid instability [26]. One part of the solution to this problem is the resolution of dimers or higher multimers to monomers by site-specific recombination. The multimer resolution site of ColE1 (designated cer, for ColE1 resolution) contains binding sites for the host-encoded recombinase XerCD and the accessory protein ArgR (Fig. 2C). They act together with PepA (whose binding site is less clearly defined) to convert dimers to monomers by site-specific recombination [27-30]. Conserved A-T tracts phased at approximately 10.5 bp intervals facilitate the curvature of the region between the ArgR and $\mathrm{XerC} / \mathrm{XerD}$ binding sites, which is thought to be 
Table 1 Strains used in this study

\begin{tabular}{|c|c|c|c|c|c|c|}
\hline Strain $^{a}$ & 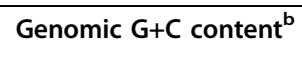 & Plasmid & Source & $\begin{array}{l}\text { Year of } \\
\text { isolation }\end{array}$ & Geographic region & Reference \\
\hline$\overline{D S M} 4594^{\text {TC }}$ & $51.7 \pm 0.5$ & pHW4594 & Water & Before 1976 & France & {$[60]$} \\
\hline DSM 30076 & $51.4 \pm 0.4$ & pHW30076 & Chicken & $1984-1988$ & Not given & [8] \\
\hline DSM 30078 & & - & Minced meat & $1984-1988$ & Not given & {$[8]$} \\
\hline CCUG $21213^{d}$ & & - & Human burn & $1984-1988$ & USA & {$[8]$} \\
\hline CCUG $48021^{e}$ & & - & Snail, intestinal content & $1984-1988$ & Germany & [8] \\
\hline CCUG $48023^{f}$ & & - & Human blood & $1984-1988$ & Germany & [8] \\
\hline WMR15 & $51.9 \pm 0.9^{9}$ & pHW15 & Pear, fruit & 2000 & Austria & {$[6]$} \\
\hline WMR39 & & - & Carrot, root & 2002 & Austria & This study \\
\hline WMR41 & & - & Carrot, root & 2002 & Austria & This study \\
\hline WMR42 & $51.5 \pm 0.2$ & pHW42 & Carrot, root & 2002 & Spain & This study \\
\hline WMR52 & & - & Carrot, root & 2002 & Austria & This study \\
\hline WMR58 & $51.8 \pm 0.7^{9}$ & - & Carrot, root & 2002 & Austria & {$[6]$} \\
\hline WMR59 & & - & Leek, root & 2002 & Austria & This study \\
\hline WMR60 & & - & Leek, root & 2002 & Austria & This study \\
\hline WMR65 & & - & Spring onion, root & 2002 & Austria & This study \\
\hline WMR66 & $51.8 \pm 0.6$ & pHW66 & Spring onion, root & 2002 & Austria & This study \\
\hline WMR67 & & - & Celery, root & 2002 & Austria & This study \\
\hline WMR70 & & - & Celery, root & 2002 & Austria & This study \\
\hline WMR75 & & - & Sugar beet, root & 2002 & Austria, Lower Austria & This study \\
\hline WMR76 & & - & Sugar beet, root & 2002 & Austria, Lower Austria & This study \\
\hline WMR77 & & - & Yellow carrot, root & 2002 & Austria & This study \\
\hline WMR79 & & - & Yellow carrot, root & 2002 & Austria & This study \\
\hline WMR81 & & - & Yellow carrot, root & 2002 & Austria & This study \\
\hline WMR82 & & - & Parsley, root & 2002 & Austria & This study \\
\hline WMR83 & & - & Parsley, root & 2002 & Austria & This study \\
\hline WMR84 & & - & Beetroot, root & 2002 & Austria & This study \\
\hline WMR86 & & - & Beetroot, root & 2002 & Austria & This study \\
\hline WMR87 & & - & Horseradish, root & 2002 & Austria & This study \\
\hline WMR88 & & - & Horseradish, root & 2002 & Austria & This study \\
\hline WMR93 & & - & Radish, root & 2002 & Austria & This study \\
\hline WMR94 & & - & Carrot, root & 2002 & Spain, Gran Canaria & This study \\
\hline WMR95 & & - & Carrot, root & 2002 & Spain, Gran Canaria & This study \\
\hline WMR97 & & - & Carrot, root & 2002 & Spain, Gran Canaria & This study \\
\hline WMR98 & & - & Carrot, root & 2002 & Spain, Gran Canaria & This study \\
\hline WMR100 & & - & Celery, root & 2003 & Germany & This study \\
\hline WMR102 & & - & Carrot, root & 2003 & Germany & This study \\
\hline WMR104 & $52.2 \pm 0.3$ & pHW104 & Carrot, root & 2003 & Germany & This study \\
\hline WMR105 & & - & Carrot, root & 2003 & Germany & This study \\
\hline WMR106 & & - & Carrot, root & 2003 & Italy & This study \\
\hline WMR107 & & - & Carrot, root & 2003 & Italy & This study \\
\hline WMR108 & & - & Carrot, root & 2003 & Italy & This study \\
\hline WMR109 & & - & Potato, tuber & 2003 & Egypt & This study \\
\hline WMR113 & & - & Leek, root & 2003 & Belgium & This study \\
\hline WMR114 & $51.3 \pm 0.2$ & pHW114A+B & Leek, root & 2003 & Belgium & This study \\
\hline WMR120 & $52.6 \pm 0.5$ & pHW120 & Carrot, root & 2005 & Spain, Tenerife & This study \\
\hline WMR121 & $52.5 \pm 0.5$ & pHW121 & Carrot, root & 2005 & Spain, Tenerife & This study \\
\hline WMR126 & $52.2 \pm 0.1$ & pHW126 & Carrot, root & 2006 & Albania & This study \\
\hline WMR128 & & - & Carrot, root & 2006 & Croatia, Dubrovnik & This study \\
\hline WMR138 & & - & Carrot, root & 2006 & Spain, La Palma & This study \\
\hline
\end{tabular}


Table 1: Strains used in this study (Continued)

\begin{tabular}{lllll}
\hline WMR140 & - & Carrot, root & 2006 & Spain, La Palma \\
WMR141 & - & Carrot, root & 2007 & This study \\
WMR143 & - & Carrot, root & 2007 & Portugal, Madeira \\
WMR144 & - & Carrot, root & $2007 \quad$ This study & Portugal, Madeira \\
\hline
\end{tabular}

${ }^{a}$ DSM strains were obtained from the Deutsche Sammlung von Mikroorganismen und Zellkulturen GmbH, Germany. CCUG strains were obtained from the

Culture Collection, University Göteborg, Sweden.

b Means and standard deviations of the mol\% G+C contents were calculated from at least three independent measurements.

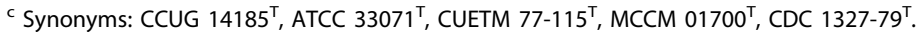

d Synonyms: CDC 658-79, MCCM 01948.

e Synonyms: SM S7/1-576, CDC 4402-96.

f Synonyms: SM Bonn 7, CDC 4418-96.

g Taken from [6].

beneficial for recombination complex formation [31,32]. These sequence elements are conserved in the mrs sites of the ColE1-like plasmids (Fig. 2C).

Multimer resolution is necessary but not sufficient to combat the threat of the dimer catastrophe. A checkpoint, mediated by the small regulatory transcript Rcd, ensures that the cell does not divide before multimers have been resolved completely to monomers [33]. Rcd binds to the enzyme tryptophanase, stimulating the production of indole which inhibits cell division by an unknown mechanism [34]. Rcd is expressed from the $\mathrm{P}_{c e r}$ promoter within cer. $\mathrm{P}_{c e r}$ is active in plasmid multimers but is repressed in monomers by FIS and XerCD [35]. A FIS binding site important for regulation of $\mathrm{P}_{c e r}$ has been mapped recently [35] (Fig. 2C).

As stated above, we observed that the multimer resolution sites of the ColE1-like plasmids were in the same orientation with respect to the replication origin (Fig. 1). In other words RNAII and $r c d$ are invariably transcribed in the same direction. A possible explanation could lie in the complex regulation of $\mathrm{P}_{c e r}$. FIS is required for high fidelity repression of the promoter in plasmid monomers but it is the lifting of XerCD-mediated repression in plasmid dimers which is thought to induce synthesis of Rcd and the inhibition of cell division [35]. The main evidence supporting this hypothesis is that, while the mutational inactivation of either XerC or XerD in a cell containing plasmid monomers gave a substantial increase in Rcd expression, there was no induction of Rcd expression when ArgR or PepA was inactivated [35]. RNAII read-through transcription entering cer (or the mrs on related plasmids) would first displace ArgR/PepA which will ensure that $\mathrm{P}_{c e r}$ remains inactive. If, however, cer was in the opposite orientation, transcription might displace XerCD, inducing transient expression of Rcd from plasmid monomers. A similar argument can be made for the progress of the replication fork through cer. In the existing orientation the fork will displace ArgR before XerCD, thus ensuring that $\mathrm{P}_{c e r}$ remains repressed during replication. Moreover, active $\mathrm{P}_{c e r}$ facing in the opposite direction might transiently stall the replication fork, since active promoters can act as replication barriers [36,37].

In addition to the replication unit and the mrs all sequenced ColE1-like plasmids possessed a conserved open reading frame with homology to excI of ColE1 (Fig. 1 and Additional file 1). ExcI was originally believed to mediate entry exclusion of homologous plasmids [38] but later it was convincingly shown that mbeD exhibits this activity [39]. Therefore the function of ExcI remains unknown.

In addition to these general features most ColE1-like plasmids contained highly conserved regions as indicated in Fig. 1. Clearly these plasmids show a highly mosaic structure. Since pHW114A and pHW114B reside in the same strain, their similarity can be potentially explained by recent recombination events in their host. However, the structures of the other plasmids argue strongly for frequent horizontal transfer within Rahnella and between Rahnella and Pectobacterium, the host of pECA1039. Interestingly, none of the ColE1-like plasmids from Rahnella possessed any known mobilisation system.

\section{pHW66 is a ColE2-like plasmid}

pHW66, like the ColE1-family plasmids, showed a hybrid structure. It possessed a ColE2-like replication system composed of a repA gene encoding the replication protein and a conserved nucleotide sequence that might function as oriV (Fig. 3). While the replication origins of ColE2-like plasmids are usually located immediately downstream of the repA gene [40], the putative oriV of pHW66 was separated from repA by an insertion of more than $2 \mathrm{~kb}$ with an unusually low $\mathrm{G}+\mathrm{C}$ content of $36 \%$ (the host strain of pHW66 has a $\mathrm{G}+\mathrm{C}$ content of $51.8 \pm 0.6 \%$; Table 1). Interestingly, this insert comprised two genes that seemed to be cistronic with repA. ORF2 showed distant similarity to a putative ATPase from Shewanella woodyi and ORF3 was weakly homologous to a hypothetical protein from Lyngbya $s p$. (Additional file 1). Whether these genes have a role in plasmid replication or maintenance cannot be predicted. 


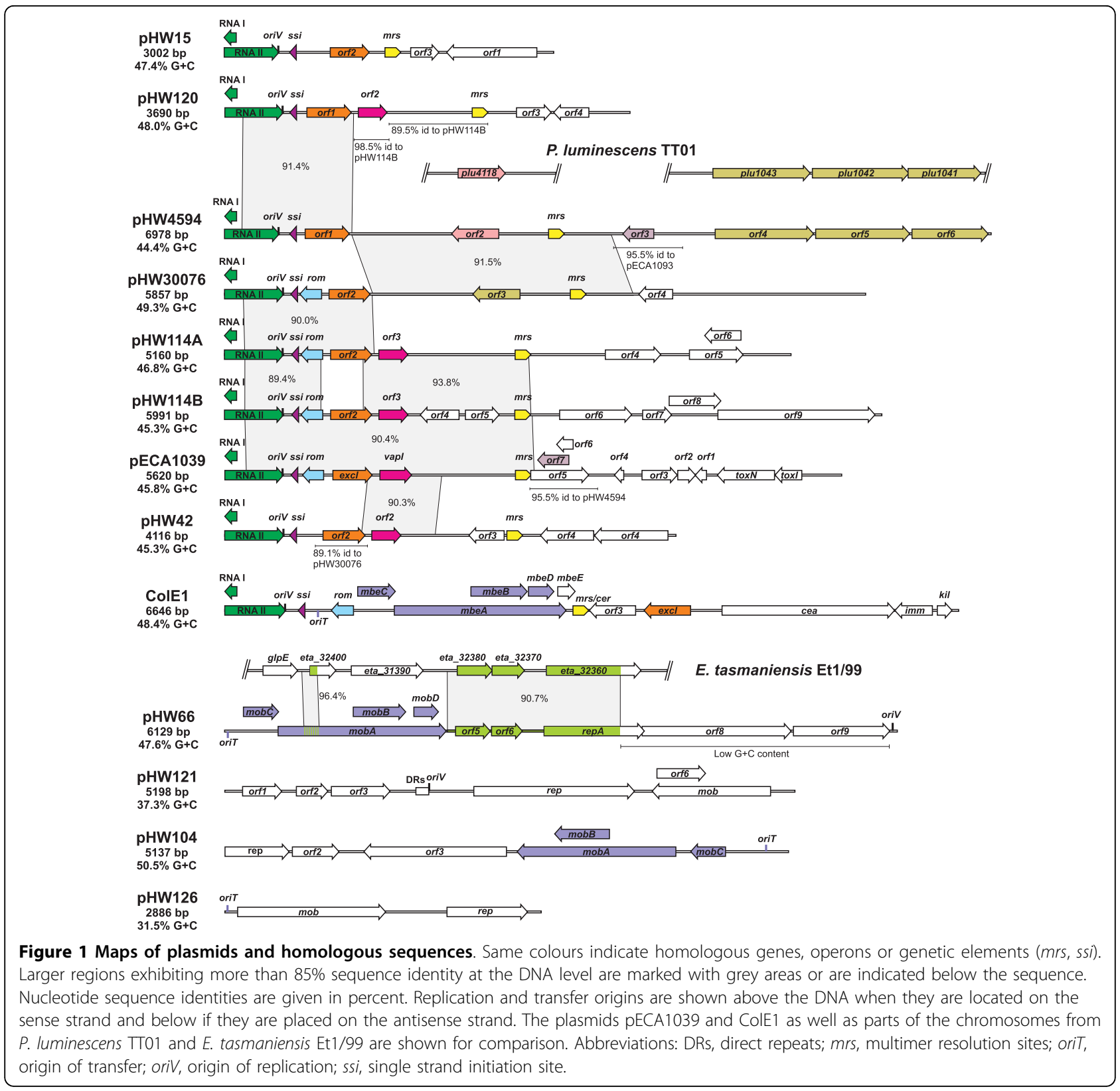

An insert of low $\mathrm{G}+\mathrm{C}$ content adjacent to repA has also been described for the ColE2-like plasmid pUB6060 [41] but the inserts of pHW66 and pUB6060 are distinct. Another module found on pHW66 was a mobilisation system of the ColE1-superfamily composed of a conserved transfer origin (oriT) and 4 genes: $m o b A, \operatorname{mobB}$, $m o b C$ and $m o b D$ [42]. Close homologues of these genes were present on pUB6060, highlighting the close relationship between pHW66 and pUB6060. It is also interesting to note that neither pHW66 nor pUB6060 possessed a XerCD-type multimer resolution system, although this type is frequent among ColE2-like plasmids [40]. The last module was located downstream of the mobilisation system and consisted of two open reading frames with remarkable homology to two consecutive genes of unknown function in the chromosome of Erwinia tasmaniensis Et1/99 [43]. The significance of this will be discussed below.

\section{Plasmids sharing homology to rolling circle replicons}

While the plasmids described above exhibited clear homology to previously classified plasmids, database searches with pHW121 retrieved only distantly-related sequences. The translated amino acid sequence of the largest ORF of pHW121 was $19 \%, 17 \%$ and $16 \%$ identical to replication proteins of pZMO1, pCA2.4 and 

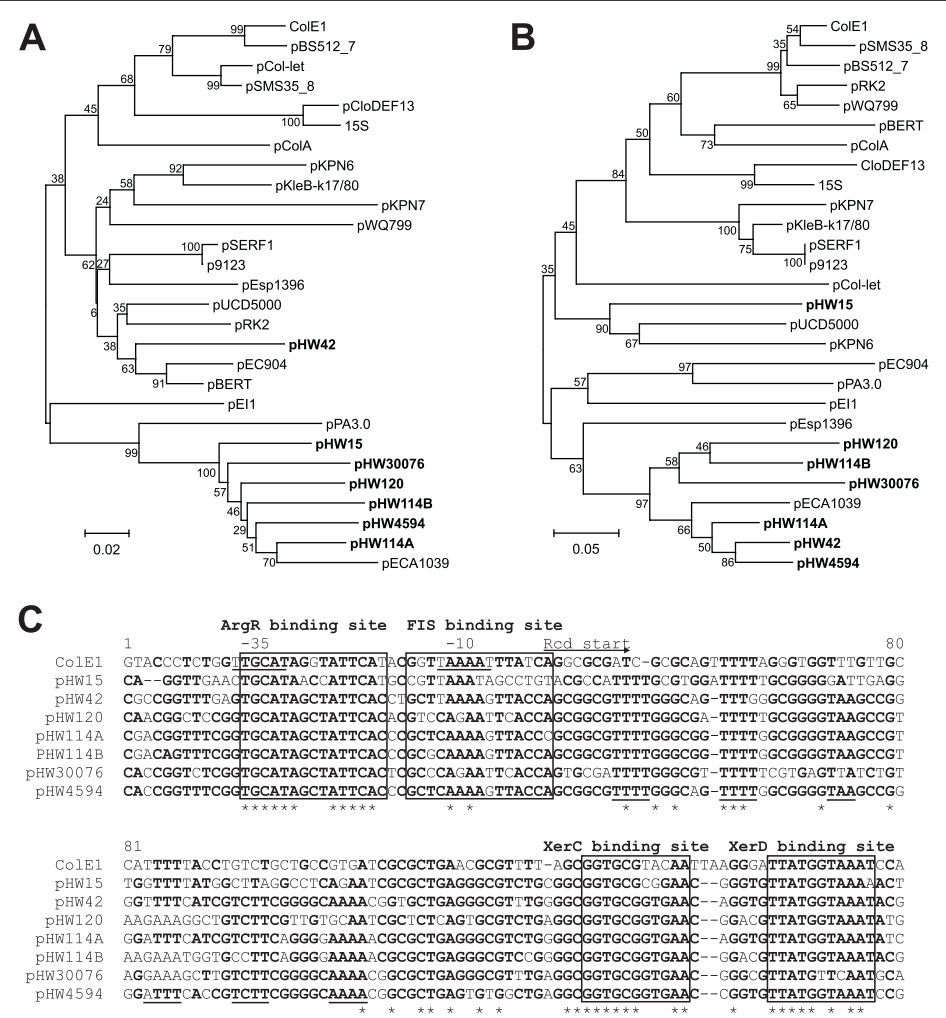

Figure 2 The ColE1-like plasmids of Rahnella form a sub-family. Phylogenetic trees were constructed based on RNA II (A) or the mrs (B). In both trees most ColE1-like plasmids isolated from Rahnella (shown in bold letters) formed a cluster with pECA1039, a plasmid of Pectobacterium artrosepticum. (C) Alignment of the multimer resolution sites. The ArgR, FIS, XerC and XerD binding sites are boxed and conserved A-T stretches responsible for DNA bending are underlined. The -10 and -35 boxes of the ColE1 $\mathrm{P}_{\text {cer }}$ promoter are underlined and the start of the Rcd coding region is indicated by an arrow. Nucleotides conserved in at least $50 \%$ of the sequences are shown in bold and invariant sites are marked with an asterisk.

pUB110, respectively (Additional file 1). Importantly, the metal binding domain showed the typical signature HUHXLUxV and the catalytic domain contained the conserved Tyr residue involved in the nucleophilic attack on the plasmid DNA at initiation of replication [44], identifying orf1 as repA and pHW121 as a member of the $\mathrm{pC} 194 / \mathrm{pUB} 110$ family. A sequence was present upstream of repA that might function as oriV (Fig. 4A).

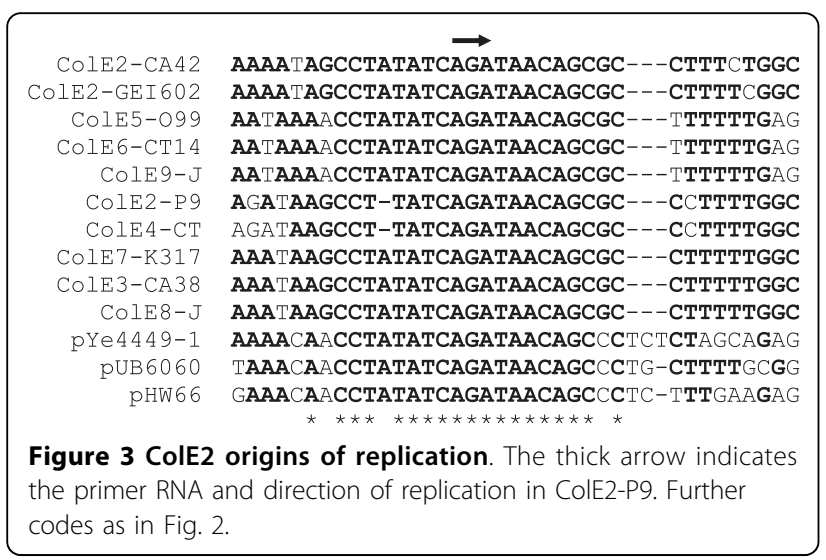

Interestingly, the putative ori $V$ was preceded by 16 perfect and 1 imperfect direct repeats of the sequence GGGTTTT. Such a motif has not been described so far for any pC194/pUB110-like plasmid. In addition, pHW121 possessed a putative mobilisation protein of the $\mathrm{MOB}_{Q}$ family. Although the homology was low, the typical motifs were present [42]. Due to a lack of conservation no putative oriT could be identified. ORF3 of pHW121 was similar to ImcC of Legionella pneumophila. Several genes of the imc/dot complex are essential for the ability of L. pneumophila to survive in macrophages during lung infection such as Legionnaires' disease. However, no function has so far been attributed to $\operatorname{ImcC}[45]$.

pHW104 showed similarity to members of a poorly studied plasmid family (Fig. 4B). A 298 amino acid protein of pHW104 showed more than $70 \%$ identity to the putative replication protein of pVCG1.2 and 22.5\% identity to RepA from pAM10.6. The involvement of the latter in replication has been proven experimentally [46]. In addition pHW104 comprised a ColE1-type 


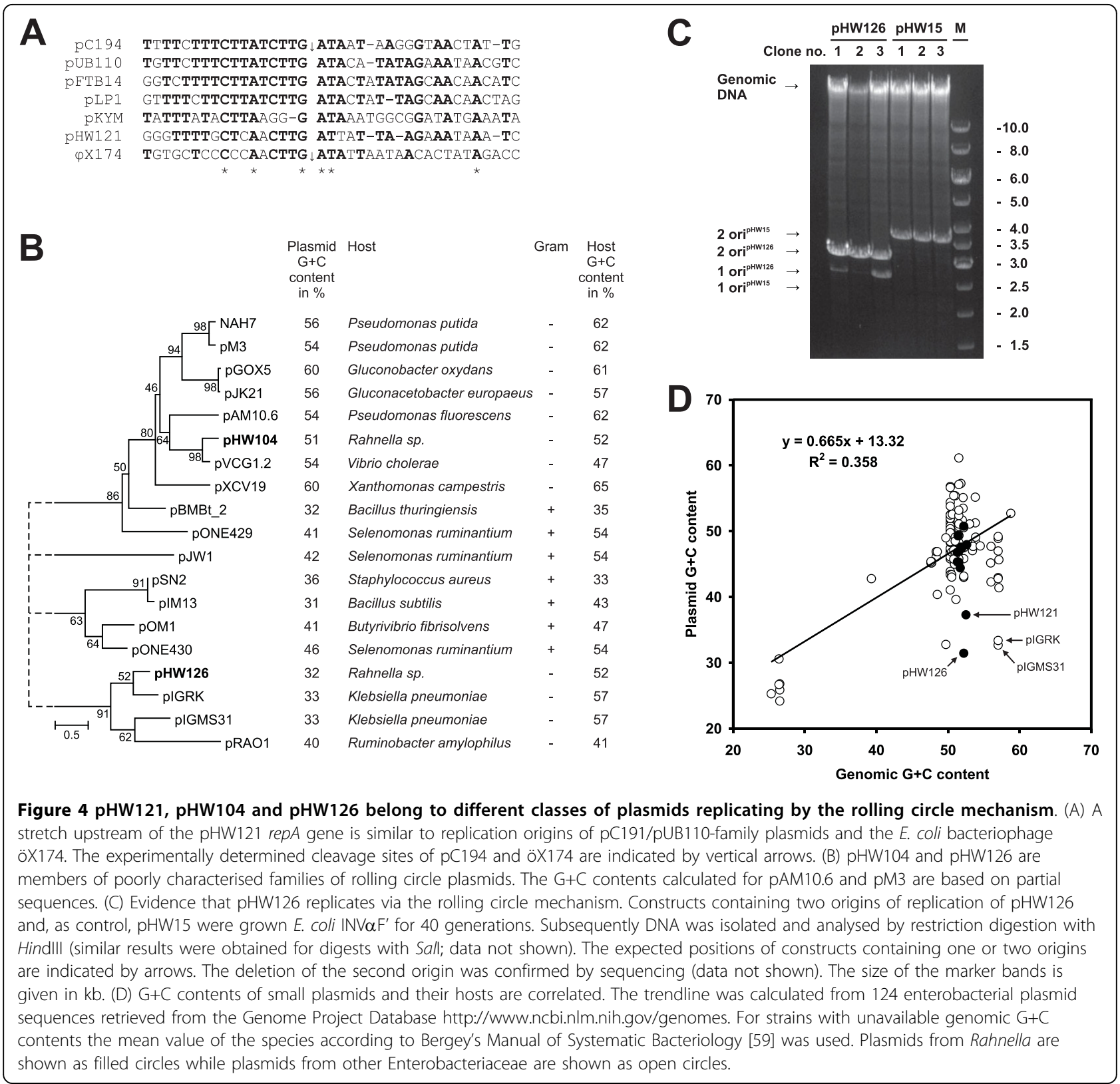

mobilisation system (Fig. 5A) and two open reading frames of unknown function.

pHW126, the smallest plasmid found in the genus Rahnella, belonged to a novel, yet uncharacterised class of plasmids. It consisted of only $2886 \mathrm{bp}$ and possessed two ORFs. ORF1 showed similarity to relaxases of the pMV158-superfamily mediating plasmid mobilisation. The characteristic motif $\mathrm{HxDExxPHxH}$, as well as an invariant Arg residue in the $\mathrm{N}$-terminus, were present [42] and a putative oriT could be identified approximately 100 bp upstream of orf1 (Fig. 5B). Thus orf1 was named mob. BLAST and FASTA searches with the translated amino acid sequence of ORF2 identified homologous sequences from two uncharacterised plasmids from Klebsiella pneumoniae, pIGRK and pIGMS31, and one plasmid from Ruminobacter amylophilus, pRAO1 (55.8\%, 26.1\%, and $22.7 \%$ identity, respectively). Iterated PSI-BLAST searches with ORF2 from pHW126 as well as with Rep from pHW104 retrieved sequences of replication proteins from pSN2like plasmids and pJW1, indicating that all these plasmids might form a super-family (Fig. 4B). However, the Rep sequence identity between members of different clades shown in Fig. 4B was around $10 \%$ in pair wise 


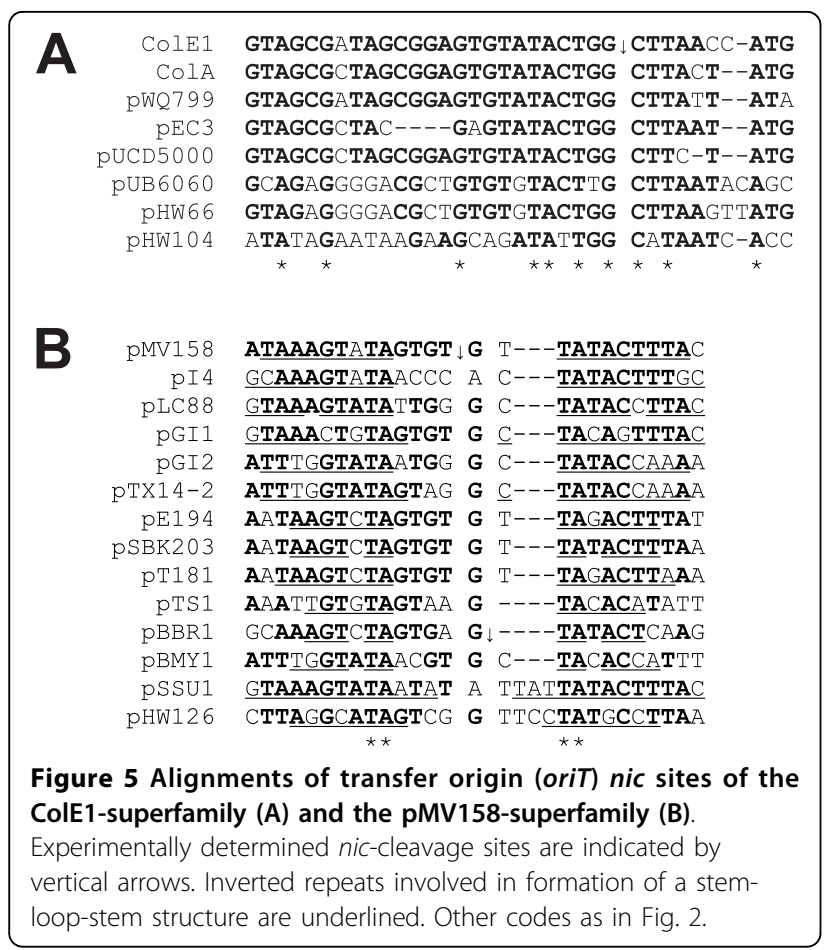

alignments and only two amino acids are invariant in all replication proteins of the plasmids analysed (Additional file 2). A final decision whether these plasmids are members of a common super-family is not possible.

The very weak similarity of pHW126 to well characterised plasmids raised the question whether pHW126 should be classified as a rolling circle plasmid. However, we observed that increasing the size of pHW126 to more than $5 \mathrm{~kb}$ by insertion of foreign DNA fragments rendered this plasmid unstable (data not shown) which is a common phenomenon for rolling circle vectors [47]. To provide further experimental evidence a construct containing the rep gene and two copies of the upstream sequences in tandem repeat was generated. These upstream sequences are presumed to contain the origin of replication which is usually located 5' of the rep gene in rolling circle plasmids. This construct was transformed into the rec $A^{-}$strain $E$. coli INV $\alpha$ F' and independent clones were grown for 40 generations. Plasmid DNA prepared from these cultures showed two bands after linearisation with restriction enzymes (Fig. 4C). The larger band of approximately $3.1 \mathrm{~kb}$ corresponded to the introduced plasmid. The smaller band, present in variable amounts, had a size of approximately $2.7 \mathrm{~kb}$, consistent with the loss of one copy of the origin of replication. Frequent deletion of one replication origin is evidence for a rolling circle replication mechanism, because replication initiated at the second origin may terminate at the first. This causes that the part of the plasmid between the two origins to be deleted [47]. As a control a similar construct containing two copies of the ori from pHW15 (a ColE1 like plasmid replicating by a theta mechanism [6]), was tested in the same way. This construct maintained both origins as indicated by presence of only one band with a size of $3.7 \mathrm{~kb}$ (deletion of one ori would have reduced the size to $2.5 \mathrm{~kb}$ ). These data provide convincing evidence that pHW126 replicates by the rolling circle replication mechanism, and that the origin of replication is located upstream of the rep gene.

Both pHW121 and pHW126 showed strikingly low G $+\mathrm{C}$ contents of only $37.3 \%$ and $31.5 \%$, respectively. Usually the $\mathrm{G}+\mathrm{C}$ contents of plasmids are correlated with the chromosomal $\mathrm{G}+\mathrm{C}$ contents of their hosts (Fig. 4B and 4D). pHW121 as well as pHW126 and its close homologues pIGRK, pIGMS31 and pRAO1 clearly deviate from this rule. Many rolling circle plasmids isolated from Gram positive bacteria have a low $\mathrm{G}+\mathrm{C}$ content [48-50] (Fig. 4B). Thus pHW126 and its homologues might have been acquired from Gram positive bacteria. On the other hand, Ruminobacter amylophilus, the host species of pRAO1, has a $\mathrm{G}+\mathrm{C}$ content of approximately $41 \%$. Recently plasmids with low $\mathrm{G}+\mathrm{C}$ content in their replication regions, which are distinct from pHW121 or pHW126, were isolated from soil bacteria. These plasmids could replicate in $E$. coli but their natural host might be Acinetobacter [51], a genus of Gram negative bacteria with a $\mathrm{G}+\mathrm{C}$ content of about $40 \%$. Also some genera of the Enterobacteriaceae, e.g. Buchnera, Hamiltonella, Proteus or Moraxella have strikingly low $\mathrm{G}+\mathrm{C}$ contents. It will be interesting to see if plasmids similar to pHW126 are isolated from such genera or from Gram positive microorganisms in the future.

\section{Evidence for horizontal exchange of genetic information between plasmids from Rahnella and bacterial chromosomes}

Several plasmids possessed genes or regions homologous to sections of enterobacterial chromosomes (Additional file 1). The most interesting examples were parts of pHW66, which were homologous to the chromosome of Erwinia tasmaniensis Et/99, and a gene cluster of pHW4594 similar to an operon of Photorhabdus luminescens TT01. Stretches of approximately $1600 \mathrm{bp}$ and $140 \mathrm{bp}$ of pHW66 had identities of more than $90 \%$ to parts of the chromosome of E. tasmaniensis Et1/99 at the nucleotide level (Fig. 1). The $140 \mathrm{bp}$ region of pHW66 was a small part of the plasmid $m o b A$ gene while the $1600 \mathrm{bp}$ region comprised orf5 and 89 bp upstream of it, orf6, the intergenic region between orf6 and repA and the main part of repA. The corresponding region on the E. tasmaniensis chromosome had a similar architecture: two small open 
reading frames of unknown function and a repA-like gene. Interestingly, while RepA proteins encoded by ColE2-like plasmids showed a high degree of similarity from the $\mathrm{N}$ - to the $\mathrm{C}$-terminus, the RepA-like protein of E. tasmaniensis Et1/99 was highly similar at the Nterminus but the last 45 amino acids were unrelated (Additional file 3). This RepA version might therefore not be functional. A BLAST search with the E. tasmaniensis Et1/99 region homologous to pHW66 indicated a hybrid structure: the 3' part harbouring the two ORFs was similar to other enterobacterial chromosomes, while the 5' part containing the truncated repA retrieved only plasmid sequences. With the full-length sequence there was no hit apart from pHW66. This region of the E. tasmaniensis Et1/99 chromosome might therefore be the result of a recent insertion of a part of a plasmid related to pHW66.

pHW4594 possessed a cluster of three genes, orf4, orf5 and orf6, that showed homology to an operon of the P. luminescens chromosome (Fig. 1). Although similar genes were also present in other genera, this particular arrangement could only be observed in $P$. luminescens. However, since the chromosome of Rahnella is not sequenced, this gene cluster of pHW4594 might also originate from the genome of its host. To test this hypothesis we investigated genomic DNA of several Rahnella strains by Southern blot analysis using a probe containing the main parts of orf5 and orf6 (Fig. 6). Only in the host strain of pHW4594, DSM $4594^{\mathrm{T}}$, a signal could be detected which corresponded to the expected restriction fragment of the plasmid itself. Signals indicative of genomic copies of orf5 and orf6 could neither be detected in DSM $4594^{\mathrm{T}}$, nor in any other strains of Rahnella aquatilis. Different strains of Rahnella genomospecies 1 and genomospecies 2 did not show any signal either. Thus, it is most likely that the orf4 orf5 orf6 gene cluster originates from P. luminescens (or another species) but not from Rahnella.

Photorhabdus is an enterobacterial symbiont of soil nematodes that infect various insects. After the nematode attacks an insect $P$. luminescens is released and produces a wide range of virulence factors ensuring rapid insect killing [52]. Recently it has been shown that Rahnella is the predominant species in the intestinal tract of the ghost moth Hepialus gonggaensis [53], indicating that Rahnella might frequently be present in insects. On the other hand, E. tasmaniensis is common on apple and pear barks and blossoms, and Rahnella has been isolated from apple and pear fruits [5,6,54]. Therefore, Rahnella seems to have overlapping habitats with P. luminescens and E. tasmaniensis, which might favour exchange of mobile genetic elements between Rahnella and these species.

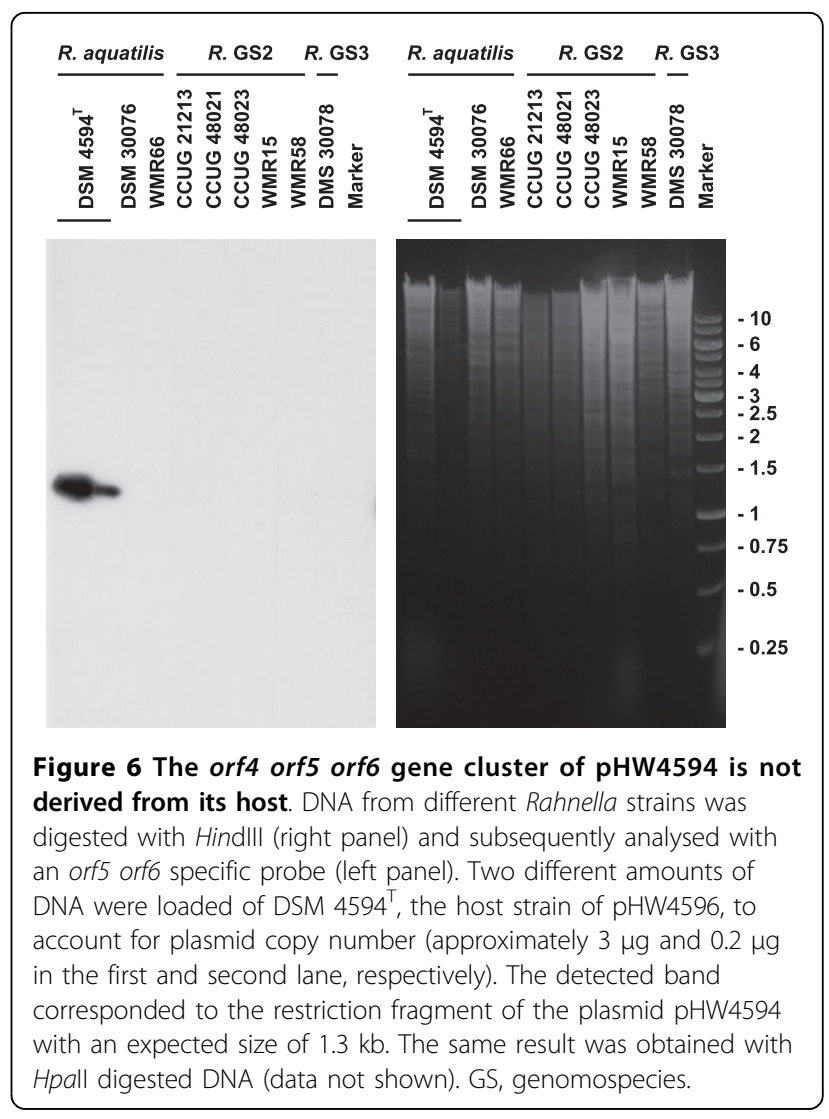

\section{Conclusions}

The frequency of small (less than $15 \mathrm{~kb}$ ) plasmids is highly variable within the Enterobacteriaceae. For instance, they are extremely rare in Citrobacter freundii while $42 \%$ of Escherichia coli isolates possess at least one plasmid [23]. For the genus Rahnella we observed plasmid-containing isolates at a frequency of $19 \%$, which is in the average range. ColE1-like plasmids were the predominant family, which is typical for enterobacterial genera. Most ColE1-like plasmids from Rahnella formed a subgroup within the ColE1 family on the basis of RNA II or mrs-based phylogenetic trees. The mrs sites of the ColE1-plasmids were arranged in a constant orientation with respect to the replication origin. Such conservation is likely to prevent inappropriate activation of the $\mathrm{P}_{c e r}$ promoter by read-through transcription or during replication. High-fidelity control of $\mathrm{P}_{c e r}$ is essential because the promoter directs expression of a small RNA that causes inhibition of cell division by stimulating indole production. The ColE1-plasmids shared extensive regions of high sequence homology in coding and in non-coding regions, indicating frequent horizontal gene transfer and recombination events among plasmids within the genus Rahnella. Interestingly, none of the ColE1-like plasmids found in this study possessed a mobilisation system. In contrast, the other plasmids 
analysed (one ColE2-like plasmid and three rolling circle plasmids) contained mobilisation genes. pHW121 is a member of the pC194/pUB110 family. pHW104 and pHW126 belong to different groups of poorly-characterised plasmids and might form a super-family with pSN2-like plasmids and pJW1. To our surprise the plasmids lacked genes which confer an obvious benefit upon their hosts. Of course some of the genes with unknown function might encode proteins with advantageous functions but at least for some of the plasmids the term "selfish DNA" seems appropriate. The best example is pHW126, the smallest plasmid found in Rahnella. This plasmid possessed only two ORFs, a putative replication gene and one for mobilisation. Since these coding sequences cover more than $70 \%$ of the plasmid, and additional regions are expected to function as oriV and oriT, the plasmid is simply too small to bear any gene beneficial to the host. The low $\mathrm{G}+\mathrm{C}$ content of this plasmid might indicate that Rahnella is not its normal host. In contrast, the close similarities among the ColE1-like plasmids provided compelling evidence that Rahnella is their normal host. The presence of genes probably derived from $P$. luminescens on pHW4594 and stretches of the chromosome of E. tasmaniensis highly homologous to parts of pHW66 highlight the importance of plasmids for genetic exchange of even chromosomal sequences among different genera.

\section{Methods}

\section{Media and growth conditions}

E. coli and Rahnella strains were grown in MLB medium $(10 \mathrm{~g} / \mathrm{l}$ peptone, $5 \mathrm{~g} / \mathrm{l}$ yeast extract, $5 \mathrm{~g} / \mathrm{l} \mathrm{NaCl}, \mathrm{pH}$ 7) at $37^{\circ} \mathrm{C}$ and $30^{\circ} \mathrm{C}$, respectively, if not otherwise indicated. When necessary, ampicillin was added to a concentration of $100 \mathrm{mg} / \mathrm{l}$.

\section{Isolation and identification of Rahnella strains}

Different types of plant materials (Table 1) were homogenised in sterile PBS and dilutions plated on LevineEMB agar (Merck, Darmstadt, Germany). After incubation at $36^{\circ} \mathrm{C}$ for $48 \pm 8 \mathrm{~h}$ dark colonies were sampled and restreaked twice on MLB plates to obtain pure cultures. Strains were classified by routine biochemical tests and partial 16S rRNA gene sequencing [6]. For amplification of the 16S rRNA gene the primer pair fD2 and $\mathrm{rP1}$ was employed. The PCR product was purified with a Nucleospin Kit (Macherey-Nagel, Düren, Germany) and directly sequenced using the primers 16S-3 and 16S-5. Primer sequences are shown in Additional file 4 .

\section{Cloning and sequencing of the plasmids}

Presence of plasmids was investigated by standard alkaline lysis miniprep [55] and subsequent agarose gel electrophoresis. The strains WMR15 and WMR58 (Table 1) were used as positive and negative controls, respectively. Plasmid DNA for cloning was isolated with a Genomed plasmid midi kit and further purified by agarose gel electrophoresis. Plasmid DNA was digested with appropriate restriction enzymes and cloned into pBluescriptIIKS $^{+}$(Stratagene, La Jolla, CA) cut with the same enzyme or an enzyme forming compatible ends. Both strands were sequenced by primer walking. A complete sequence for each plasmid was obtained by assembling individual reads with ContigExpress from the VectorNTI package (Invitrogen, Carlsbad, CA).

\section{Sequence annotation and phylogenetic analysis}

Plasmid DNA sequences and predicted open reading frames were used for BLAST, PSI-BALST and FASTA databank searches at the genebank http://www.ncbi.nlm. nih.gov and ddbj http://www.ddbj.ac.jp websites. AlignX from the VectorNTI package was used to identify further less conserved or short elements e.g. ori $V$, oriT or ssi sites. The same program was employed to calculate the global identity of plasmid ORFs and sequences retrieved from databases. Phylogentic analyses were performed with MEGA4 [56]. Neighbour-joining (NJ) trees were constructed using the p-distance model for DNA and the JTT matrix for amino acid sequences. Positions with gaps were usually completely deleted except for alignments containing highly diverse sequences, where pair wise deletion was chosen. Bootstrap values were calculated from 1000 replicates and indicated at the corresponding nodes. Almost identical tree topologies were obtained with other methods (minimum evolution and UPGMA) and models (Poisson correction, PAM). G+C contents of plasmids were calculated using ARTEMIS 10 [57].

\section{Detection of ori deletion}

pHW126 was digested with BglII and HindIII and the $1463 \mathrm{bp}$ fragment containing the putative rep gene and the upstream intergenic sequences cloned into pBKanT [6] linearised with BamHI/HindIII. The resulting construct, designated $\mathrm{pB} 126 \Delta \mathrm{BH}$, was digested with SpeI, the $446 \mathrm{bp}$ fragment isolated and cloned into the same construct digested with $\mathrm{XbaI}$ which led to construct pB126-2ori. This construct was used to assay replication origin deletion: pB126-2ori was digested with SalI and the fragment containing the $\operatorname{Kan}^{\mathrm{R}}$ gene and the pHW126 sequences isolated by agarose gel electrophoresis. The purified DNA was diluted to a concentration of $1 \mathrm{ng} / \mu \mathrm{l}$ and self-circularised by incubation with $1 \mathrm{U} \mathrm{T} 4$ ligase for $1 \mathrm{~h}$ at room temperature in a total reaction volume of $20 \mu \mathrm{l}$ leading to pHW1262ori. After transformation into E. coli INV $\alpha$ F' the cells were plated on MLB-kanamycin $(30 \mu \mathrm{g} / \mathrm{ml})$ plates 
and incubated overnight at $37^{\circ} \mathrm{C}$. Three individual colonies were transferred completely to $100 \mathrm{ml}$ MLBKan medium each and grown overnight. Plasmid DNA was isolated from these cultures using a Genomed plasmid midi kit as recommended by the manufacturer. Formation of plasmids containing only one pHW126 origin of replication was observed by agaraose gel electrophoresis after digestion with HindIII or Sall. For confirmation, both bands were cut out, extracted with a Macherey-Nagel gel extraction kit and used as a template for PCR amplification with the primer pair pHW126-11/Kan rev. The amplification product was cleaned and directly sequenced employing the same primers as used for PCR. As a control pHW15-2ori, which possesses two pHW15 origins of replication in tandem repeat, was tested in the same way. pB15In(NsiI) was constructed by inserting pHW15 [6] linearised with NsiI into pBKanT. Subsequently, this construct was linearised with HindIII and Pst I and ligated with the 1218 bp fragment obtained by digesting pBKanT-pHW15 $\Delta(\mathrm{ORF} 1+2+3)$ [6] with HindIII and NsiI. This led to construct pB15-2ori which was finally digested with SalI and self-circularised to obtain pHW15-2ori.

\section{Southern blot analysis}

Approximately $3 \mu \mathrm{g}$ genomic DNA were digested with an appropriate restriction enzyme and separated by agarose gel electrophoresis. After denaturation with 0.5 $\mathrm{M} \mathrm{NaOH}$, neutralisation with $5 \times \mathrm{TBE}$ and equilibration with $1 \times$ TBE the DNA was transferred to a Hybond- $\mathrm{N}^{+}$ membrane (GE Healthcare, Buckinghamshire, UK) by semi-dry electroblotting using $1 \times \mathrm{TBE}$ as transfer buffer. Cross linking was achieved by irradiation with $120 \mathrm{~mJ} /$ $\mathrm{cm}^{2} \mathrm{UV}$ of $254 \mathrm{~nm}$. Subsequently, the membrane was pre-hybridised with Church buffer [58] containing 100 $\mu \mathrm{g} / \mathrm{ml}$ freshly denaturated herring sperm DNA. The probe was prepared by PCR: a $50 \mu \mathrm{l}$ reaction contained 1 U GoTaq (Promega, Madison, WI), $10 \mu \mathrm{l} 5 \times$ buffer containing $\mathrm{Mg}^{2+}, 1 \mathrm{ng}$ pHW4594 as template, $1 \mu \mathrm{l}$ primer mix (pHW4594-fwd/pHW4595-rev; each $5 \mu \mathrm{M}$ ), 1 $\mu \mathrm{l}$ nucleotide mix $(0.5 \mathrm{mM}$ each of dATP, dGTP and dTTP and $0.05 \mathrm{mM} \mathrm{dCTP})$ and $30 \mu \mathrm{Ci}\left[\alpha{ }^{32} \mathrm{P}\right]$-dCTP $(3000 \mathrm{Ci} / \mathrm{mmol}$; PerkinElmer, Waltham, MA). After an initial denaturation step at $94^{\circ} \mathrm{C}$ for 5 min 35 cycles of $94^{\circ} \mathrm{C}$ for $30 \mathrm{sec}, 50^{\circ} \mathrm{C}$ for $1 \mathrm{~min}$ and $72^{\circ} \mathrm{C}$ for $2 \mathrm{~min}$ were performed prior a final extension step at $72^{\circ} \mathrm{C}$ for $10 \mathrm{~min}$. The denaturated amplicon $\left(95^{\circ} \mathrm{C}, 10 \mathrm{~min}\right)$ was added to the blocked membrane and hybridised for $18 \mathrm{~h}$ at $60^{\circ} \mathrm{C}$. The membrane was washed 5 times with $0.05 \%$ SDS in $1 \times$ SSC [51] at $60^{\circ} \mathrm{C}$ and once with distilled water at room temperature. Signals were detected by autoradiography.

\section{Determination of genomic $\mathrm{G}+\mathrm{C}$ contents}

The genomic DNA $\mathrm{G}+\mathrm{C}$ contents of selected strains were determined by HPLC analysis as described previously [6].

\section{Nucleotide sequence accession numbers}

Plasmids sequences obtained in this study were deposited in the EMBL nucleotide sequence database with the following accession numbers: [EMBL:FN429021], pHW42; [EMBL:FN429022], pHW114A; [EMBL: FN429023], pHW114B; [EMBL:FN429024], pHW120; [EMBL:FN429025], pHW4594; [EMBL:FN429026], pHW30076; [EMBL:FN429027], pHW66; [EMBL: FN429028], pHW121; [EMBL:FN429029], pHW104; [EMBL:FN429030], pHW126. Accession numbers retrieved from databases are listed in Additional file 5.

\footnotetext{
Additional file 1: Annotation of the open reading frames. A table with annotation details of the open reading frames of all plasmids isolated in this study is shown.

Click here for file

[http://www.biomedcentral.com/content/supplementary/1471-2180-1056-S1.PDF]

Additional file 2: Alignment of replication proteins. The data provide an alignment of the replication proteins of pHW104, pHW126 and related plasmids.

Click here for file

[http://www.biomedcentral.com/content/supplementary/1471-2180-1056-S2.PDF ]

Additional file 3: The RepA-like protein of the E. tasmaniensis Et/99 chromosome diverges at its C-terminus from plasmid RepA proteins. The data provide an alignment of the RepA sequences of pHW66, pYe4449-1 and pUB6060 and the RepA-like gene of the $E$. tasmaniensis Et1/99 chromosome.

Click here for file

[http://www.biomedcentral.com/content/supplementary/1471-2180-1056-S3.PDF ]

Additional file 4: Primers used in this study. The data provide the sequences of primers used in this study. Click here for file

[http://www.biomedcentral.com/content/supplementary/1471-2180-1056-S4.PDF ]

Additional file 5: Accession numbers of sequences retrieved from databases. This table provides the accession numbers of sequences retrieved from databases and used for construction of phylogenetic trees and alignments.

Click here for file

[http://www.biomedcentral.com/content/supplementary/1471-2180-1056-S5.PDF ]
}

\section{Acknowledgements}

This work was supported by the Lower Austrian State Academy and the Austrian Science Fund. MK and BK received fellowships from the the Higher Education Commission of Pakistan and the Austrian Science Fund, respectively. Thanks to Juliane Mayerhofer for providing plant material from Madeira, Portugal and to Jürgen Mairhofer, Peter Prištas and Sigrid Husar for helpful tips and comments.

\section{Author details}

${ }^{1}$ Max F Perutz Laboratories, University of Vienna, Dr Bohrgasse 9, 1030 Vienna, Austria. ${ }^{2}$ Albrecht-von-Haller-Institute of Plant Sciences, GeorgAugust-University Goettingen, Untere Karspuele 2, 37073 Goettingen, 
Germany. ${ }^{3}$ Department of Genetics, University of Cambridge, Downing Street, Cambridge CB2 3EH, UK.

\section{Authors' contributions}

WR conceived the study and was involved in all stages of experimental work and data analysis and drafted the manuscript. EP participated in strain isolation and manuscript preparation. MK participated in database searches and sequence annotation. DKS interpreted the results regarding the multimer resolution sites. BP participated in data analysis and helped to draft the manuscript. All authors read and approved the final manuscript.

Received: 17 July 2009

Accepted: 19 February 2010 Published: 19 February 2010

\section{References}

1. Berge O, Heulin T, Achouak W, Richard C, Bally R, Balandreau J: Rahnella aquatilis, a nitrogen-fixing enteric bacterium associated with the rhizosphere of wheat and maize. Can J Microbiol 1991, 37:195-203.

2. Heulin T, Berge O, Mavingui P, Gouzou L, Hebbar KP, Balandreau J: Bacillus polymyxa and Rahnella aquatilis, the dominant $\mathrm{N}_{2}$-fixing bacteria associated with wheat rhizosphere in French soils. Eur J Soil Biol 1994, 30:35-42.

3. Hashidoko Y, Itoh E, Yokota K, Yoshida T, Tahara S: Characterization of five phyllosphere bacteria isolated from Rosa rugosa leaves, and their phenotypic and metabolic properties. Biosci Biotechnol Biochem 2002, 66:2474-2478.

4. Cankar K, Kraigher $H$, Ravnikar M, Rupnik M: Bacterial endophytes from seeds of Norway spruce (Picea abies L. Karst). FEMS Microbiol Lett 2005, 244:341-345.

5. Lindow SE, Desurmont C, Elkins R, McGourty G, Clark E, Brandl MT: Occurrence of indole-3-acetic acid producing bacteria on pear trees and their association with fruit russet. Phytopathology 1998, 88:1149-1157.

6. Rozhon WM, Petutschnig EK, Jonak C: Isolation and characterization of pHW15, a small cryptic plasmid from Rahnella genomospecies 2. Plasmid 2006, 56:202-215.

7. Niemi RM, Heikkilä MP, Lahti K, Kalso S, Niemelä SI: Comparison of methods for determining the numbers and species distribution of coliform bacteria in well water samples. J Appl Microbiol 2001, 90:850-858.

8. Brenner DJ, Müller HE, Steigerwalt AG, Whitney AM, O'Hara CM, Kämpfer P: Two new Rahnella genomospecies that cannot be phenotypically differentiated from Rahnella aquatilis. Int J Syst Bacteriol 1998, 48:141-149.

9. Rhodes AN, Urbance JW, Youga H, Corlew-Newman H, Reddy CA, Klug MJ, Tiedje JM, Fisher DC: Identification of bacterial isolates from intestinal contents associated with 12,000-year-old mastodon remains. Appl Environ Microbiol 1998, 64:651-658.

10. Beazley MJ, Martinez RJ, Sobecky PA, Webb SM, Teillefert M: Uranium biomineralization as a result of bacterial phosphatase activity: Insights from bacterial isolates from a contaminated subsurface. Environ Sci Technol 2007, 41:5701-5707.

11. El-Hendawy HH, Osman ME, Sorour NM: Biological control of bacterial spot of tomato caused by Xanthomonas campestris pv. vesicatoria by Rahnella aquatilis. Microbial Res 2005, 160:343-352.

12. Laux P, Baysal Ö, Zeller W: Biological control of fire blight by using Rahnella aquatilis Ra39 and Pseudomonas spec. R1. Acta Hort 2002, 590:225-229.

13. Kim KY, Jordan D, Krishnan HB: Rahnella aquatilis, a bacterium isolated from soybean rhizosphere, can solubilize hydroxyapatite. FEMS Microbio Lett 1997, 153:273-277.

14. Kim H, Park H-E, Kim M-J, Lee HG, Yang J-Y, Cha J: Enzymatic characterization of a recombinant levansucrase from Rahnella aquatilis ATCC 15552. J Microbiol Biotechnol 2003, 13:230-235

15. Pintado ME, Pintado AIE, Malcata FX: Production of polysaccharide by Rahnella aquatilis with whey feedstock. J Food Sci 1999, 64:348-352.

16. Seo J-W, Jang K-H, Kang SA, Song K-B, Jang EK, Park B-S, Kim CH, Rhee S-K: Molecular characterization of the growth phase-dependent expression of the IsrA gene, encoding levansucrase of Rahnella aquatilis. J Bacteriol 2002, 184:5862-5870.

17. Carinder JE, Chua JD, Corales RB, Taege AJ, Procop GW: Rahnella aquatilis baceteremia in a patient with relapsed acute lymphoblastic leukemia. Scand J Infect Dis 2001, 33:471-473.
18. Chang $\mathrm{CL}$, Jeong J, Shin JH, Lee EY, Son HC: Rahnella aquatilis sepsis in an immunocompetent adult. J Clin Microbiol 1999, 37:4161-4162.

19. Tash K: Rahnella aquatilis bacetremia from a suspected urinary source. $J$ Clin Microbiol 2005, 43:2526-2528.

20. Bellais S, Poirel L, Fortineau N, Decousser JW, Nordmann P: Biochemicalgenetic characterization of the chromosomally encoded extendedspectrum class A $\beta$-lactamase from Rahnella aquatilis. Antimicrob Agents Chemother 2001, 45:2965-2968.

21. Lindberg A-M, Ljungh $\AA$, Ahrné S, Löfdahl S, Molin G: Enterobacteriaceae found in high numbers in fish, minced meat and pasteurised milk or cream and the presence of toxin encoding genes. Int J Food Microbiol 1998, 39:11-17.

22. Stock I, Grüger T, Wiedemann B: Natural antibiotic susceptibility of Rahnella aquatilis and R. aquatilis-related strains. J Chemother 2000, 12:30-39.

23. Sherley M, Gordon DM, Collignon PJ: Species differences in plasmid carriage in the Enterobacteriaceae. Plasmid 2003, 49:79-85.

24. Fineran PC, Blower TR, Foulds IJ, Humphreys DP, Lilley KS, Salmond GP: The phage abortive infection system, ToxIN, functions as a protein-RNA toxin-antitoxin pair. Proc Natl Acad Sci USA 2009, 106:894-899.

25. Summers DK, Beton CW, Withers HL: Multicopy plasmid instability: the dimer catastrophe hypothesis. Mol Microbiol 1993, 8:1031-1038.

26. Summers DK, Sherratt DJ: Multimerization of high copy number plasmids causes instability: ColE1 encodes a determinant essential for plasmid monomerization and stability. Cell 1984, 36:1097-1103.

27. Blakely G, May G, McCulloch R, Arciszewska LK, Burke M, Lovett ST, Sherratt DJ: 2 related recombinases are required for site-specific recombination at dif and cer in Escherichia coli K12. Cell 1993, 75:351-361.

28. Colloms SD, Sykora P, Szatmari G, Sherratt DJ: Recombination at ColE1 cer requires the Escherichia coli xerC gene product, a member of the lambda integrase family. J Bacteriol 1990, 172:6973-6980.

29. Stirling CJ, Colloms SD, Collins JF, Szatmari G, Sherratt DJ: xerB, an Escherichia coli gene required for plasmid ColE1 site-specific recombination is identical to pepA, encoding aminopeptidase $A$, a protein with substantial similarity to bovine lens leucine aminopeptidase. EMBO Journal 1989, 8:1623-1627.

30. Stirling CJ, Szatmari G, Stewart G, Smith MCM, Sherratt DJ: The arginine repressor is essential for plasmid stabilizing site-specific recombination at the ColE1 cer locus. EMBO Journal 1988, 7:4389-4395.

31. Hodgman TC, Griffiths H, Summers DK: Nucleoprotein architecture and ColE1 dimer resolution: a hypothesis. Mol Microbiol 1998, 29:545-558.

32. Summers DK, Sherratt DJ: Resolution of ColE1 dimers requires a DNA sequence implicated in the three-dimensional organization of the cer site. EMBO Journal 1988, 7:851-858.

33. Patient ME, Summers DK: ColE1 multimer formation triggers inhibition of E. coli cell division. Mol Microbiol 1993, 8:1089-1095.

34. Chant EL, Summers DK: Indole signalling contributes to the stable maintenance of Escherichia coli multicopy plasmids. Mol Microbiol 2007 63:35-43.

35. Blaby IK, Summers DK: The role of FIS in the Rcd checkpoint and stable maintenance of plasmid ColE1. Microbiology 2009, 155:2676-2682.

36. McGlynn P, Guy CP: Replication forks blocked by protein-DNA complexes have limited stability in vitro. J Mol Biol 2008, 381:249-255

37. Mirkin EV, Mirkin SM: Mechanisms of transcription-replication collisions in bacteria. Mol Cell Biol 2005, 25:888-895.

38. Chan PT, Ohmori H, Tomizawa J, Lebowitz J: Nucleotide sequence and gene organization of ColE1 DNA. J Biol Chem 1985, 260:8925-8935.

39. Yamada Y, Yamada M, Nakazawa A: A ColE1-encoded gene directs entry exclusion of the plasmid. J Bacteriol 1995, 177:6064-6068.

40. Hiraga $S$, Sugiyama T, Itoh T: Comparative analysis of the replicon regions of eleven ColE2-related plasmids. J Bacteriol 1994, 176:7233-7243.

41. Avison MB, Walsh TR, Bennett PM: pUB6060: a broad-host-range, DNA polymerase-l-independent ColE2-like plasmid. Plasmid 2001, 45:88-100

42. Francia MV, Varsaki A, Garcillán-Barcia MP, Latorre A, Drainas C, de la Cruz F: A classification scheme for mobilization regions of bacterial plasmids. FEMS Microbiol Rev 2004, 28:79-100.

43. Kube M, Migdoll AM, Müller I, Kuhl H, Beck A, Reinhardt R, Geider K: The genome of Erwinia tasmaniensis strain Et1/99, a non-pathogenic bacterium in the genus Erwinia. Environ Microbiol 2008, 10:2211-2222. 
44. del Solar G, Giraldo R, Ruiz-Echevarría MJ, Espinosa M, Díaz-Orejas R: Replication and control of circular bacterial plasmids. Microbiol Mol Biol Rev 1998, 62:434-464

45. Morozova I, Qu X, Shi S, Asamani G, Greenberg JE, Shuman HA, Russo JJ: Comparative sequence analysis of the $\mathrm{icm} / \mathrm{dot}$ genes in Legionella. Plasmid 2004, 51:127-147.

46. Peters $M$, Jõgi $E$, Suitso I, Punnisk $T$, Nurk $A$ : Features of the replicon of plasmid pAM10.6 of Pseudomonas fluorescens. Plasmid 2001, 46:25-36.

47. Gruss A, Ehrlich SD: The family of highly interrelated single-stranded deoxyribonucleic acid plasmids. Mirobiol Rev 1989, 53:232-241.

48. Delver EP, Belogurova NG, Tupikova EE, Varfolomeyev SD, Belogurov AA: Characterization, sequence and mode of replication of plasmid pNB2 from the thermophilic bacterium Clostridium thermosaccharolyticum. Mol Gen Genet 1996, 253:166-172.

49. Khan SA, Novick RP: Complete nucleotide sequence of pT181, a tetracycline-resistance plasmid from Staphylococcus aureus. Plasmid 1983 10:251-259.

50. Zou X, Caufield PW, Li Y, Qi F: Complete nucleotide sequence and characterization of pUA140, a cryptic plasmid from Streptococcus mutans. Plasmid 2001, 46:77-85.

51. Heuer H, Kopmann C, Binh CT, Top EM, Smalla K: Spreading antibiotic resistance through spread manure: characteristics of a novel plasmid type with low \%G+C content. Environ Microbiol 2009, 11:937-949.

52. Duchaud E, Rusniok C, Frangeul L, Buchrieser C, Givaudan A, Taourit S, Bocs S, Boursaux-Eude C, Chandler M, Charles JF, Dassa E, Derose R, Derzelle S, Freyssinet G, Gaudriault S, Médigue C, Lanois A, Powell K, Siguier $P$, Vincent R, Wingate $V$, Zouine $M$, Glaser $P$, Boemare $N$, Danchin A, Kunst $F$ : The genome sequence of the entomopathogenic bacterium Photorhabdus luminescens. Nat Biotechnol 2003, 21:1307-1313.

53. Yu H, Wang Z, Liu L, Xia Y, Cao Y, Yin Y: Analysis of the intestinal microflora in Hepialus gonggaensis larvae using $16 \mathrm{~S}$ rRNA sequences. Curr Microbiol 2008, 56:391-396.

54. Geider K, Auling G, Du Z, Jakovljevic V, Jock S, Völksch B: Erwinia tasmaniensis sp. nov., a non-phytopathogenic bacterium from apple and pear trees. Int J Syst Bacteriol 2006, 56:2937-2943.

55. Sambrook J, Russell DW: Molecular Cloning: A Laboratory Manual Cold Spring Harbor, Cold Spring Harbor Laboratory Press 2001

56. Tamura K, Dudley J, Nei M, Kumar S: MEGA4: Molecular Evolutionary Genetics Analysis (MEGA) software version 4.0. Mol Biol Evol 2007, 24:1596-1599.

57. Carver T, Berriman M, Tivey A, Patel C, Böhme U, Barrell BG, Parkhill J, Rajandream MA: Artemis and ACT: viewing, annotating and comparing sequences stored in a relational database. Bioinformatics 2008 24:2672-2676

58. Church GM, Gilbert W: Genomic sequencing. Proc Natl Acad Sci USA 1984 81:1991-1995

59. Brenner DJ, Farmer JJ: Enterobacteriales. Bergey's Manual of Systematic Bacteriology SpringerBrenner D, Krieg NR, Staley JT, Garrity GM 2005, 2(Part B):587-848.

60. Gavini F, Ferragut $\mathrm{C}$, Lefebvre $\mathrm{B}$, Leclerc $\mathrm{H}$ : E' tude taxonomique d'ente'robacte'ries appartenant ou apparente'es au genre Enterobacter. Ann Microbiol (Paris) 1976, 127B:317-335.

\section{Submit your next manuscript to BioMed Central and take full advantage of:}

- Convenient online submission

- Thorough peer review

- No space constraints or color figure charges

- Immediate publication on acceptance

- Inclusion in PubMed, CAS, Scopus and Google Scholar

- Research which is freely available for redistribution

Submit your manuscript at www.biomedcentral com/submit 